\title{
Agricultural Production Efficiency of Bethma Cultivation in Mahaweli System H
}

\author{
S. Thiruchelvam*
}

\begin{abstract}
This study attempts to examine the agricultural productivity and efficiency of owner cultivators and sharecroppers, under Bethma cultivation in two Irrigation Units in the Madatugama block of the Mahaweli System H area. A stochastic frontier production function analysis reveals significant differences between productivity and technical efficiency among these types of cultivators during Yala 2004. One of the key reasons for such a result is the lack of land tenure security, which inhibits any long-term investments in shared land. Stronger farmer organizations were more likely to be efficient in productivity and technical efficiency than weaker ones. This suggests the need for strengthening the farmer organizations to increase agricultural production efficiency under the Bethma system.
\end{abstract}

\section{Introduction}

Water management under dry conditions assumes great importance in a tropical region such as Sri Lanka where half the cropped area is affected by frequent drought. Share cultivation practice adopted to overcome this problem during the dry season has been the cause for the relatively low agricultural productivity and land degradation in the shared land. Due to inadequate studies, the actual extent of the problem in Bethma/Share cultivation both in economic and environmental terms is unknown in Sri Lanka.

The major problem in many irrigation projects in Sri Lanka is irrigation water shortage for cultivation during the Yala season. Even though the original objective of several resettlement schemes was to supply water throughout the year, poor management and frequent droughts have prevented such an achievement. The adopted Bethma practice in the Mahaweli System $\mathrm{H}$ irrigation scheme is an ancient system and has been practised successfully by the farmers in the traditional old village tanks during the drought seasons. The problems experienced now show that this old system or concept might

The author is Senior Lecturer, Department of Agricultural Economics and Business Management, Faculty of Agriculture, University of Peradeniya. 
not hold good for equitable distribution of irrigation water and efficient production under new conditions. Therefore, new managerial practices need to be evolved and this study is an attempt to explore this in the Mahaweli System $\mathrm{H}$ area.

Under the Bethma system of management, the available water, whatever be its quantum, is equitably allocated to all farmers in the command area. This principle invariably imposes water scarcity conditions, which necessarily lead to the adoption of more efficient practices not only by the managers but the farmers as well. The system has its focus on equity in irrigation water distribution. Similar negotiated systems are found in Tamil Nadu (Sakthivadivel and Raju, 1996) and elsewhere in Southern India. In this, land close to the tanks is assigned to each farmer in proportion to the extent of land that she/he holds. This implies that the farmers who cultivated land immediately below the tank temporarily lose their right to that land and as a condition to receive water should share the land with farmers who have no irrigation facility in the same area and raise crops as agreed at the cultivation meeting. Due to the limitations in the total quantity of water available for utilisation, growing of cash crops, which require less water than rice, was envisaged under this system so as to maximise the number of beneficiaries and productivity. This view suggests that crop diversification is essential to the problem of water shortages and to increase productivity. Thus temporary allocation of land during Yala under Bethma would help in intensive cultivation of cash crops efficiently. Therefore, this paper investigates how the owner and the sharecropper agreements under Bethma with regard to land cause differences in agricultural productivity and efficiency in the Mahaweli System H area.

Land is at the heart of the production mode of agrarian communities, and thus problems relating to land will have a direct impact on their livelihood. While the relationship between land security and productivity has been widely studied, little is known whether the productivity differential is due to inefficient resource allocation or due to the use of less productive resources or both. To date no analysis has been done to explicitly measure the level of inefficiency that may exist for tenant and owner operated lands under the same resource base, government policies, and crop. Lack of such analysis will have weak and inadequate policy implications, which may fall short of achieving the desired goal. Literature on land tenure has revealed that, as income increases, the incidence of land disputes and land grabbing, and tenure 
insecurity increases (Reddy, 2002). Insecurity in ownership of land has negative impacts on productivity. The primary way ownership security impacts on farm productivity are via its effect on the supply of investment capital available to farmers.

Several methods have been developed to determine the most efficient production frontier by different researchers (Farrel, 1957; Timmer, 1970; Aigner, et al., 1977 and Meeusen and Van den Broeck, 1977). Battese (1992) proved that the econometric modelling of frontier production functions provides useful insights into best practice technology and the measures by which the productivity efficiency of different firms may be compared. Despite its well-known limitations, the Cobb-Douglas functional form has been widely used in farm efficiency analysis for both developing and developed countries. Ekanayake and Jayasuriya (1987) and Karunaratne and Herath (1989) estimated both deterministic and stochastic frontier production of the Cobb-Douglas type for rice and other field crops in the Mahaweli System H. They found no significant technical inefficiency among farmers at the head ends. Studies of Bethma in the traditional village context have been carried out by a number of authors in a very descriptive manner (Leach, 1961; Perera 1986; Abeyrathna and Perera, 1986; de Jong, 1989). They paid attention to land ownership, and the rights and privileges that are associated with Bethma. Farmer organization is important for the successful implementation of the Bethma cultivation programme. Since many facilities to farmers are channelled through farmer organizations, it is generally accepted that farmers who participate in farmer organization activities are likely to get more benefits and obtain higher level of production than non-participants in farmer organization activities. A recent study by Thiruchelvam (2004) on the performance of Distributory Canal Farmer Organizations (DCFO) in the Mahaweli System $\mathrm{H}$ revealed that in comparison with efforts in other countries, the achievements of the DCFO under Participatory Irrigation Management (PIM) show considerable promise for achieving objectives set by the government and by local associations. However, there have been no empirical studies of the effects of farmer organization on the efficiency in agricultural production. Against this background, this study seeks to examine the agricultural productivity and efficiency and the factors affecting technical efficiency under Bethma cultivation in the Madatugama block of the Mahaweli System H area. 


\section{Methodology}

Technical efficiency of a farmer is defined as the ratio of the observed output to the frontier output that could be produced by a farm operating at $100 \%$ efficiency; if high the inefficiency is zero. When the dependent variable is expressed in log form, Battese and Coelli (1992) and Battese and Coelli (1993) have shown that this is determined mathematically as: $T E=e^{U_{i}}$. This transformation constrains the technical efficiency of each farmer to values between zero and one and this is related in inverse proportion to the inefficiency effect. It is important to distinguish technical efficiency from technological change. Technical efficiency measures the ability to produce the maximum output from the given set of inputs and production technology. Technical efficiency is measured as the deviation $\left(e^{U_{i}}\right)$ of the individual farmer from the best practice Frontier, which is assumed to be stochastic corresponding to additive two-sided error term $V_{i}$, exogenous shock and one sided error term $U_{i}$, representing technical efficiency or deviation in technical efficiency. Technical efficiency of a farm is defined in terms of the ratio of the observed output $\left(Y_{i}\right)$ or input $(X)$ to the corresponding frontier output $\left(Y^{*}\right)$ or input $\left(X^{*}\right)$. Thus the technical efficiency of a farm i in the context of the stochastic frontier production function $f\left(X_{i} \beta\right) e^{V_{i}-U_{i}}$ is the same expression as for the deterministic $f\left(X_{i}, \beta\right) e^{V_{i}}$ frontier model thus,

Technical efficiency:

$$
T e=Y * / Y=f(X \beta) e^{v_{i}-U_{i}} / f\left(X_{i}, \beta\right) e^{V_{i}}=e^{U_{i}}
$$

It is evident that productivity growth may be achieved through technological progress or efficiency improvement and the polices required to address these two issues are likely to be quite different (Coelli, 1995). Farell (1957) distinguished between technical and allocative efficiency leading to the measurement of economic efficiency.

It may be noted that the production function form $f(X \beta) e^{v_{i}-U_{i}}$ does not depict a purely technical relationship between inputs and outputs for the mere reason that input prices and expected product prices varied across the study area and influenced farmers' input use and production decisions. With the underlying influence of prices, efficient combination of input is no longer 
a purely technical decision but also relies on economic judgment. Therefore, the results of technical efficiency ultimately have to be referred to in terms of economic efficiency.

The model employed for the stochastic production function of individual farm economic efficiencies in this study is in the form of the Coelli and Battese (1996) inefficiency model. However, the effects of inputs on productivity in the ownership and other socio-economic domains were explicitly incorporated as dummies (e.g. dummy for ownership, part-time farming). This procedure avoids the problem of omitted variables. The final model was derived by, first, fitting Ordinary Least Squares (OLS) models experimentally before estimating by maximum likelihood methods. This procedure also helped to check on econometric problems, e.g. endogeneity and multicollinearity existing in the data. The multicollinearity problem was over come by having a small number of explanatory variables. The stochastic frontier production function is basically specified as a composed error model of the general form:

$$
\operatorname{Ln}\left(Y_{i}\right)=F\left(X_{i}, \beta\right)+\varepsilon_{i} \quad i=1,2 \ldots N ; \quad \varepsilon_{i}=v_{i}-u_{i}
$$

The estimated production function was of the form:

$$
\operatorname{Ln}\left(Y_{i}\right)=\sum \beta_{i} \ln \left(X_{i}\right)+v_{i}-u_{i}
$$

where $Y_{i}$ is (the logarithm of) kilograms of production produced by the $i^{\text {th }}$ farmer. Here since two crops were mainly taken, the outputs were aggregated to a single output index using a formula described below; $F$ is the CobbDouglas functional form; $X_{i}$ are the vector of (the logarithm of) inputs used by the $i^{\text {th }}$ farmer. The term $v_{i}$ is a symmetric error, which accounts for random variations in output due to factors beyond the control of the farmer, e.g. weather and disease outbreak, and it is assumed to be independently and identically distributed as $N\left(0, \sigma_{V}^{2}\right)$. The term $U_{i}$ is a non-negative variable representing inefficiency in production relative to the stochastic frontier. The distribution of $U_{i}$ is also assumed to be independent and identical as $N(0$, $\sigma u^{2}$ ) which could be half-normal at zero mean, truncated half-normal (at mean $m$ ), and based on conditional expectation of the exponential $\left(-U_{i}\right)$. Along with the $\beta$ coefficients the variance parameters are to be estimated, which are expressed in terms of: 


$$
\begin{aligned}
& \sigma_{s}^{2}=\sigma_{v}{ }^{2}+\sigma^{2} \\
& \gamma=\sigma^{2} / \sigma_{s}{ }^{2}
\end{aligned}
$$

where the $\gamma$ parameter has value between zero and one. The original specification has been used in a vast number of empirical applications over the past two decades. The efficiency indices obtained for individual farms were subsequently regressed in a second stage against some socio-economic variables. Critics on this use of two steps procedure noted a significant problem with this two-stage approach, i.e. the assumption of independent and identical distribution of the inefficiency effects is violated in the second stage when they are made to be a number of farm specific factors with no identical distribution.

In this study both functions of a single stage Maximum Likelihood (MLE) procedure as in the computer software, FRONTIER version 4.1 (Coelli, 1995) has been used for this study for each management unit separately. The following output index $Y_{i}$ was employed:

$$
Y_{i}=\sum_{i=1}^{n} P_{i} Q_{i} / \sum_{i=1}^{n} \bar{P} / N
$$

where $Y_{i}$ is the normalized output for the $i^{\text {th }}$ farm, s denotes the number of differentiated outputs, $P_{i j}$ denotes the price of the $j^{\text {th }}$ product for the $i^{\text {th }}$ farm, $Q_{i j}$ denotes the quantity produced in the $j^{\text {th }}$ product for the $i^{\text {th }}$ farm. The average price in the denominator is defined as

$$
\bar{P}=\sum_{i=1}^{n} P i Q i / Q \quad Q=\sum_{i=1}^{n} Q i
$$

The following hypotheses were developed and tested to investigate the problem:

1. The level of productivity and technical efficiency of agricultural production is the same between owners and sharecroppers under Bethma cultivation. 
2. The factors affecting technical efficiency in agricultural production of owners and sharecroppers are the same.

3. Farmers participation in farmer organization activities has no relationship with technical efficiency

The following form of the Cobb-Douglas model was used in the analysis:

$$
\begin{gathered}
\operatorname{Ln}\left(Y_{i}\right)=\beta_{0}+\beta_{1} \ln X_{1}+\beta_{2} \ln X_{2}+\beta_{3} \ln X_{13}+\beta_{24} \ln X_{4} \\
+\beta_{5} \ln X_{5}+\varepsilon_{i} \\
\quad i=1,2 \ldots N \quad \varepsilon_{i}=v_{i}-u_{i}
\end{gathered}
$$

where $\ln$ denotes logarithms to base $e$.

$$
\begin{aligned}
& Y=\text { Output index } \\
& X_{1}=\text { Extent of land (ha) } \\
& X_{2}=\text { Cost of labour (man days) } \\
& X_{3}=\text { Cost of machinery/ power (Rs.) } \\
& X_{4}=\text { Cost of agrochemicals including fertilizer cost (Rs.) } \\
& X_{5}=\text { Cost of seeds (Rs.) }
\end{aligned}
$$

The inefficiency model specified by Battese and Coelli (1993) is as follows:

$$
U_{i}=\delta_{0}+\delta_{1} Z_{1}+\delta_{2} Z_{2}+\delta_{3} Z_{3}+\delta_{4} Z_{4}+\delta_{5} Z_{5}+\delta_{6} Z_{6}
$$

where,

$Z_{i}$ represents factors contributing to inefficiency.

$Z_{l}=$ Ownership dummy (Sharer cropper $=1$ or Owner cultivator $\left.=1\right)$

$Z_{2}=$ Farming category dummy $($ Part time $=1$ or Full time $=0)$

$Z_{3}=$ Age (years)

$Z_{4}=$ Debt level dummy $($ High $=1$ or Low $=0)$

$Z_{5}=$ Farmer participation score $($ Very High $=5$ to Very Low $=1$ )

$Z_{6}=$ Distance from home dummy $($ Far $=1$ or Near $=0)$

\section{Study Area, Sampling and Data Collection}

This study was conducted in the Madatugama block during September - December 2004, and three data collection methods were 
employed, namely surveys, open-ended interviews and review of project records and other published literature. Madatugama block covers about 4,500 hectares of irrigated land with about 5,000 farmer settlers. This block was selected purposely as a high potential cultivation area among the nine blocks in the Mahaweli System H.

Out of four irrigation units in the Madatugama block, 101 Madatugama and 103 Alogomuwa irrigation management units were selected purposely for conducting the study. Unit 101 is located at the head end and unit 103 is located at the tail end of the Kandalama tank. There are distinct and striking differences in water availability and in the performances of the farmer organizations between these two irrigation units. Due to higher water scarcity, unit 103 has larger number (30) of agro-wells than unit 101, which has only 5 agro-wells. Further, it was reported that the performance of the farmer organization in unit 101 was more successful than in unit 103. Units 101 and 103 cover 1,057 ha and 911 ha of irrigable land respectively. About 1000 settlers cultivate in each unit. The Kandalama tank, which receives water from the Mahaweli river diversion, supplies water to the units 101 and 103 through the right bank-main channel. A two stage stratified random sampling procedure was undertaken in order to capture the real representation of the problem. At the first stage farmers cultivating chillie and onion were stratified and in the second stage owners and the tenant cultivators were stratified. Finally, through the random sampling scheme a total of 45 owners and 45 share cultivators were interviewed in each irrigation management unit for Yala 2004. Thus data were collected from 90 farmers for the study.

\section{Results and Discussion}

\section{Agricultural Productivity}

In System $\mathrm{H}$ it has been the practice of the farmers to cultivate the full available extent (100\%) in Maha (mostly paddy). In Yala they could cultivate only limited extent (usually 60\%) mostly with other field crops, thus having a crop intensity of $160 \%$. This is not by choice of the farmers but they are compelled to do so due to limited water availability to the system. Though irrigation in System $\mathrm{H}$ is limited, the average farmer still prefers paddy cultivation, which has the highest water duty. Yet paddy brings a minimal economic return to the farmers' efforts. This is clearly observed in the cropping pattern in the Madatugama Block. The extents of paddy and other 
field crops cultivated in the Yala season from 1997 to 2003 are shown in Figure 1.

Figure 1: $\quad$ Cropping pattern in Yala, Mahaweli System H 1997 - 2004

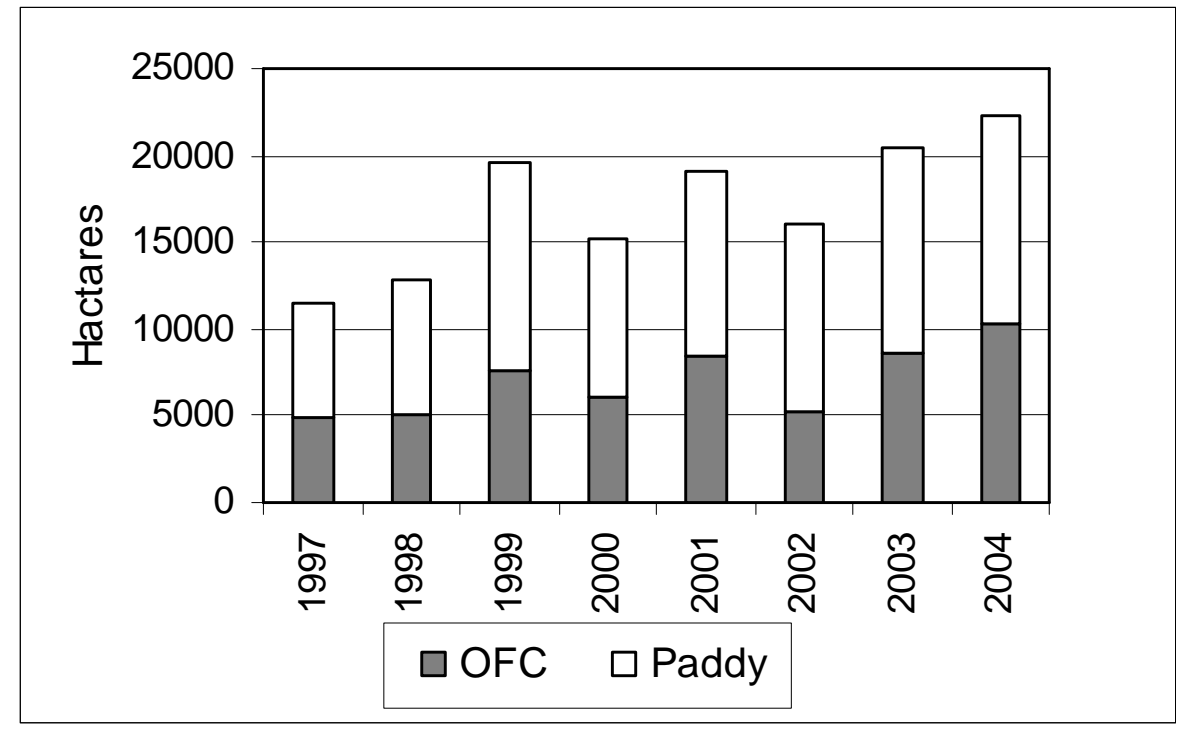

Source: Mahaweli Authority of Sri Lanka, Thambuththegama.

Paddy occupies almost $95 \%$ of the land during Maha while paddy, chillie, onion, soyabean, pulses and vegetables are grown in Yala. The choice of crops depends on the land suitability, water availability and profitability of crops in Yala under Bethma system. Further investigation reveals that both paddy and other field crops cultivation are on the increase over time from $20 \%$ to $44 \%$ of the total irrigable extent. Farmers cultivating more paddy than the targeted paddy extent has been the major problem for the management. Cultivation of other field crops in Yala has increased form 39\% of the area in 1997 to $70 \%$ in 2004 . Farmers have shifted to low water consuming crops.

Figure 2 shows that the crops grown in the blocks 101 and 103 were dominated by paddy, $46 \%$ and $50 \%$ respectively. Chillie and big onion crops follow. The current average yield levels, cost and returns of cultivation of chillie and big onion grown under Bethma in the units 101 and 103 by owner and share cultivators are shown in Table 1. This reveals that there was no 
significant yield difference between owner cultivators in unit 101 and 103 . There were significant yield differences of $18 \%$ and $15 \%$ in chillie and big onion production between owner and the share cultivators respectively in unit 103. Also there was a significant yield difference of $7 \%$ and $10 \%$ in chillie and big onion production respectively in unit 101. The reasons for the higher yield difference were owners getting the most productive land and having better access to irrigation. ANOVA test carried out confirms that the difference between the mean values were significantly different in unit 103 but, not in unit 101. Further, there was on the part of share cultivators less concern on the incentive for long-term productivity of the land. This could be the reason for less effort that resulted in less productivity. However this has not been fully reflected in this study.

Figure 2: $\quad$ Cropping pattern in Madatugama 101 and 101 units - Yala 2004

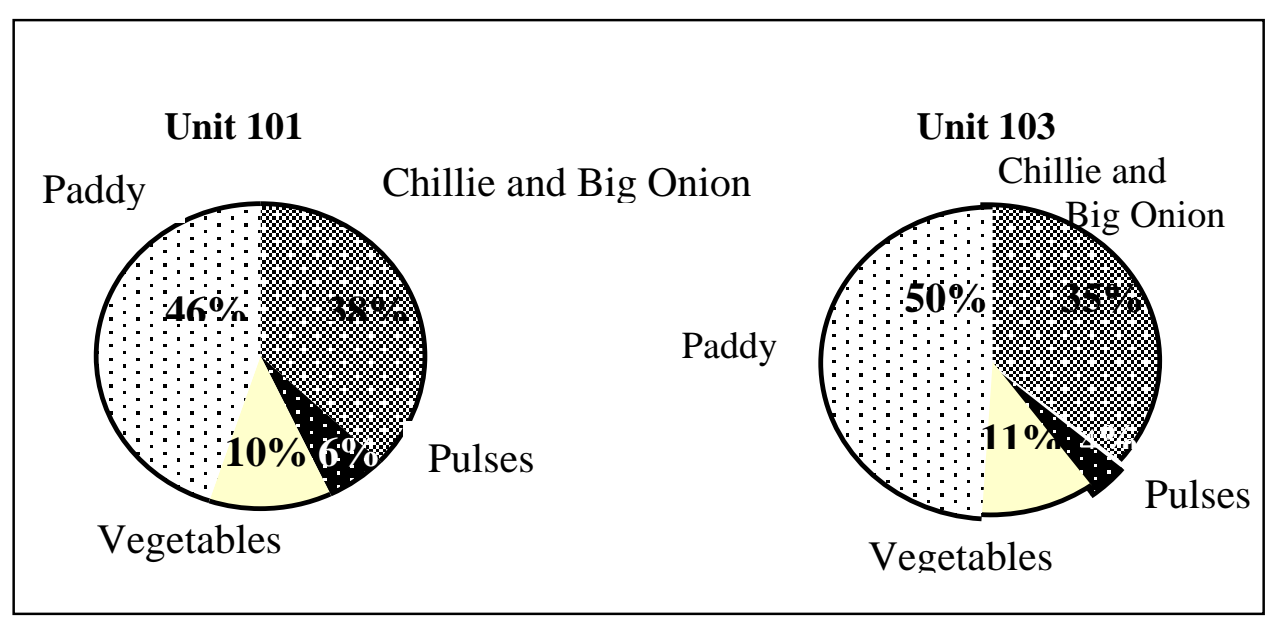

Source: Madatugama Mahaweli Block Office 
Table 1: $\quad$ Yields, costs and returns of crops grown under Bethma System Yala 2004, irrigation units 101 and 103, Madatugama block

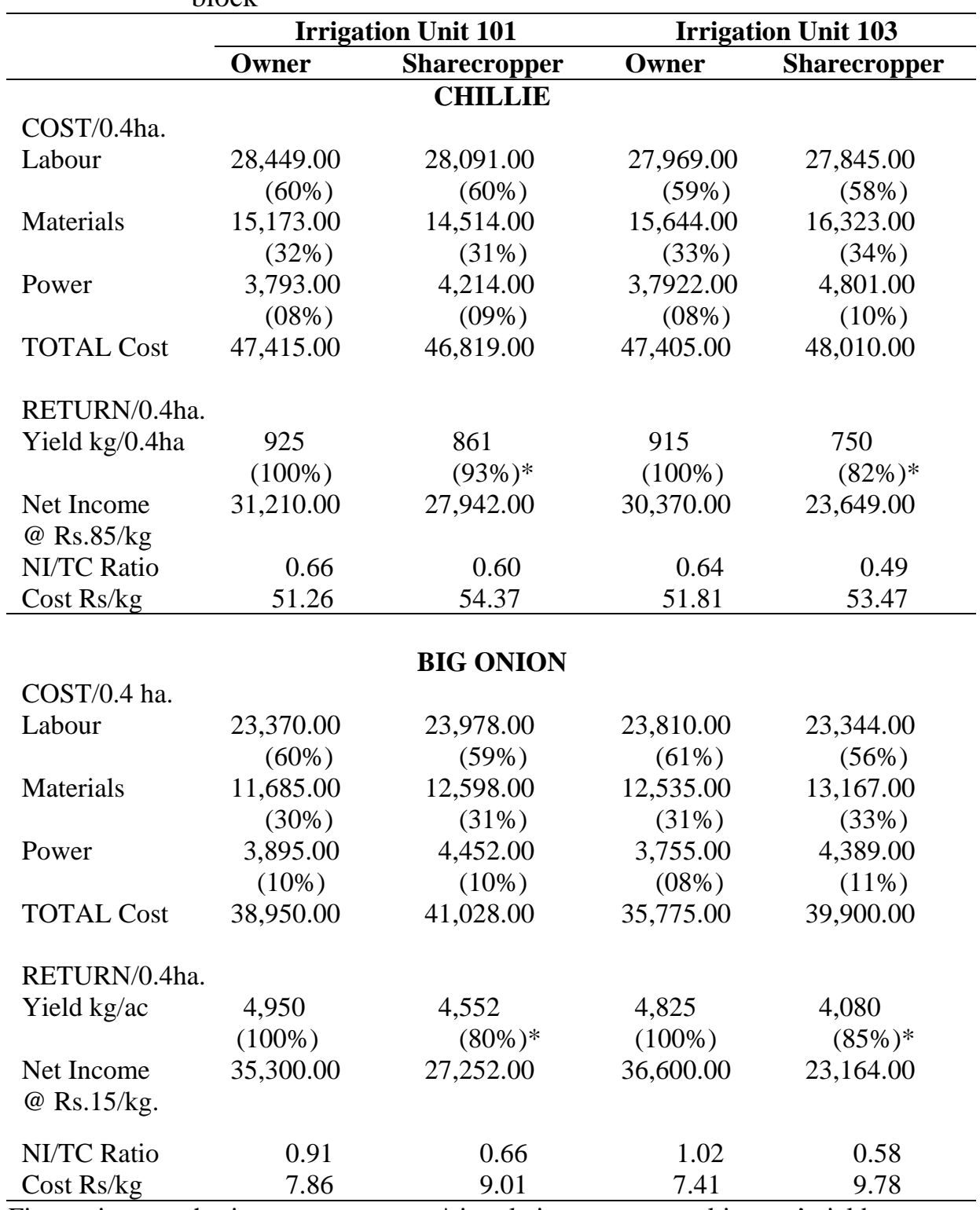

Figures in parenthesis are percentages, * in relation to owner cultivators' yield. 
The investigation on cost and returns reveals that more than half the share cultivators earn less than Rs. 35,000.00 during Yala season (April August) from Bethma cultivation. It was recognized from the study that about $30 \%$ of the owner cultivators are doing well, producing $1,200 \mathrm{~kg} / 0.4$ ha. chillie, $12,000 \mathrm{~kg} / 0.4 \mathrm{ha}$. Big onion earns more than Rs. 50,000.00 during Yala season. About $10 \%$ of settlers have own wells with adequate resources and are engaged in cash crop cultivation without joining the Bethma cultivation.

Cost and net incomes including family labour were higher in the case of owner cultivators than the share cultivators in both units. This was due to more investment in long-term investment for soil and water conservation and the higher productivity of the owners' portion. From the analysis of data, of the area under different crops for Yala season in 2004, it can be seen that the intensity of high value crops is more under the owners than in the shared portion. It is also evidenced that the distance of the allocated lands far from their home affects investment of the share cultivators. The reason why share cultivators do not follow profit maximization activities may be due to change of land quality in the next season. Since farmers know the contract is expiring at the end of the season, they would apply less organic manure. The study further evidenced that the longer the times that a farmer has cultivated the same plot, the more intensively he will use land saving inputs. Insecurity of the land could be minimized through farmer organization activities. Quality of land, credit and markets are the other factors that need consideration along with this. In unit 103 share cultivators applied less labour (5\%) and organic fertilizer to cultivation when compared to the owner cultivators.

Table 1 highlights that cost and productivity was higher among owner cultivators. Labour and fertilizer were comparatively used less among the share cultivators. This reflects intensive cultivation was high among owner cultivators. The net return total cost ratios explain that big onion was twice as (0.95) profitable as chillie cultivation (0.75) and these ratios were higher among owners than share cultivators in both units.

\section{Agricultural Productivity and Technical Efficiency Estimation}

The Maximum Likelihood estimates for the parameters for stochastic frontier and the inefficiency model are shown in Table 2 . The values of the likelihood ratios (LR) are 30.159 and 20.709, sigma-square) and gama $(\gamma)$ 0.841 and 0.794 for units 101 and 103 respectively. $\sigma^{2}$ and $\gamma$ are significantly 
different from zero in both units indicating a good fit and that the majority of error variation is due to the inefficiency error $u_{i}$ (and not due to the random error $v_{i}$ )

Table 2: $\quad$ Maximum likelihood estimates for parameters of stochastic frontier production function and inefficiency function for Units 101 and 103 in Madatugama block.

\begin{tabular}{lllll}
\hline \multirow{2}{*}{ Variables } & \multicolumn{2}{c}{ Unit 101 } & \multicolumn{2}{c}{ Unit 103 } \\
\cline { 2 - 5 } & Coefficient & t- ratio & Coefficient & t- ratio \\
\hline Stochastic frontier $\boldsymbol{\beta}$ & & & & \\
Intercept & $4.1289^{* *}$ & 3.0723 & $3.5025^{* *}$ & 2.6658 \\
Land (ac.) & $0.4358^{* * *}$ & 3.6961 & $0.3481^{* * *}$ & 9.1085 \\
Labour (man days) & $0.1631^{* *}$ & 1.9371 & $0.1981^{* *}$ & 1.7281 \\
Power (Rs.) & -0.1041 & -0.7978 & 0.0953 & 0.9605 \\
Agrochemicals (Rs.) & $-0.1509 * * *$ & -5.5311 & $-0.1907 * *$ & 3.4615 \\
Seeds (Rs.) & 0.0539 & 1.1165 & 0.0746 & 1.0955 \\
Inefficiency effects $\delta$ & & & & \\
Ownership & $-1.9322^{* *}$ & 1.5854 & $-0.7492^{* *}$ & 3.4293 \\
Farming category dummy & 0.0239 & 1.5669 & 0.3449 & 1.4547 \\
Age (years) & 0.1543 & 0.8286 & 0.5669 & 0.4544 \\
Debt Level dummy & $0.1526^{* * *}$ & 5.3782 & $0.4385 * * *$ & 6.1634 \\
Participation in FO activites & $-0.3492^{* * *}$ & 7.1293 & $-0.5386^{* *}$ & 1.7457 \\
Distance home dummy & 0.0581 & 0.7173 & 0.3784 & 0.977 \\
Sigma squared, $\sigma_{s}^{2}$ & $0.2107 * * *$ & 2.028 & $0.2276^{* * *}$ & 2.0127 \\
Gama $\gamma^{2}=\sigma_{s}^{2} / \sigma^{2}$ & $0.7421^{* * *}$ & 20.1564 & $0.9123^{* * *}$ & 18.183 \\
Log likelihood (LLF) & 30.159 & & 20.709 & \\
Sample size & 45 & & 45 & \\
ANOVA between units & $\mathrm{F}_{7.552}=15.153$ & $(0.000)$ & & \\
\hline$* * *$ Significant at $1 \%$ level,** Significant at $5 \%$ level and $*$ Significant at $10 \%$ level.
\end{tabular}

This indicates that the random component of the inefficiency effects does make a significant contribution in the analysis. According to the results, land, agrochemicals and labour were significant at $1 \%$ and 5\% levels respectively in both units. The higher land elasticity of 0.34 and 0.44 in both units, suggests output could be increased by a larger proportion by better soil conservation and land saving technology. 
The second most important variable that increases agricultural production was labour having output elasticises of 0.3631 and 0.1981 in units 101 and 103 respectively. Labour being the highest cost component accounting for over $60 \%$, could be intensified with more family labour to increase the production. However, significant negative value for chemicals indicates over use and its negative effect on production.

\section{Technical Efficiencies of Owner and Share Cultivators}

The estimated technical efficiencies for unit 101 and 103 are shown in Table 3. The results indicate a higher average technical efficiency among owners, 0.87 and 0.89 in unit 101 and unit 103 respectively and lower technical efficiency among share cultivators, 0.77 and 0.65 , in unit 101 and 103 respectively. There are no significant differences among the owner cultivators between unit 101 and unit 103. The average technical efficiency among share cultivators compared to the owner cultivators in unit 103 is significantly low at $24 \%$ and it is $11 \%$ in unit 101 .

Technical efficiency results are presented in Table 3. Since all settlers have the same resources in terms of soil type, land holding and irrigation water, it follows that the share cultivators can achieve much higher income levels than at present if their capital constraints to production and farmer organization activities are clearly defined and promoted. Table 3 shows that in both units, $26 \%$ and $53 \%$ of the farmers had low technical efficiency in units 101 and 103 respectively. However, only $34 \%$ and $12 \%$ of the farmers were having high level of technical efficiency in units 101 and 103 respectively. The lower percentage of the farmers under high level of technical efficiency in unit 103 is a critical fact. It may be inferred from this result that 53\% farmers in unit 103 who were operating at low technical efficiency should improve to the average technical efficiency. However, due to microenvironment and soil condition differences all the farmers cannot attain higher or close to average technical efficiency, and the best farmers possibility of reaching $100 \%$ of the present technology also cannot be expected. The average yield of the best farmers who represent $23 \%$ of the population should be improved through technological change in seed, appropriate mechanization and wise use of chemicals. F-test used for equality of the means rejected the null hypothesis of equal technical efficiency among owners and share cultivators and indicates a statistically significant

difference. Further technical efficiency cannot be exactly captured when 
there are difficulties in incorporating environmental factors such as soil, topography etc. in the model. The economical level of technical adoption level needs investigation. Addressing technical efficiency without economic efficiency would give a wrong interpretation. Transfer of technical efficiency to economic efficiency is needed.

Table 3: $\quad$ Frequency distribution of farm-specific technical efficiency

\begin{tabular}{lcccc}
\hline $\begin{array}{c}\text { Technical } \\
\text { Efficiency } \\
(\boldsymbol{\%})\end{array}$ & \multicolumn{2}{c}{ Unit 101 } & \multicolumn{2}{c}{ Unit 103 } \\
\cline { 2 - 5 } & $\mathbf{O w n e r}$ & $\begin{array}{c}\text { Share } \\
\text { Cultivator } \\
\mathbf{\%}\end{array}$ & $\begin{array}{c}\text { Owner } \\
\mathbf{\%}\end{array}$ & $\begin{array}{c}\text { Sharecropper } \\
\mathbf{\%}\end{array}$ \\
\hline $50-60$ & 0 & 0 & 0 & $30(12)$ \\
$61-70$ & $5(2)$ & $10(4)$ & $10(4)$ & $35(14)$ \\
$71-80$ Low & $25(10)$ & $23(9)$ & $20(8)$ & $20(6)$ \\
$81-90$ Average & $40(16)$ & $42(17)$ & $3815)$ & $15(4)$ \\
$91-100$ High & $30(12)$ & $25(10)$ & $32(13)$ & $10(4)$ \\
Maximum & 0.984 & 0.973 & 0.982 & 0.921 \\
Minimum & 0.790 & 0.622 & 0.662 & 0.520 \\
Average & 0.873 & 0.765 & 0.889 & 0.651 \\
CV & 6.7 & 5.8 & 8.1 & 13.6 \\
ANOVA F Test & \multicolumn{2}{c}{27.83} & (d.f 3: 76) F. Critical Value: 2.72 \\
\hline
\end{tabular}

Figures in parentheses indicate the number of farmers.

\section{Factors Affecting Technical Efficiency}

Causes of inefficiency in farms were determined with the production frontier in a single stage maximum likelihood estimate. The results presented in Table 2 indicate that inefficiency exits among share cultivators. The ownership dummy was significant and had a negative sign in both units. This indicates that ownership was affecting the technical efficiency among share cultivators. However this evidence is not complete and conclusive. Among the other determinants of technical efficiency, debt level had a higher significant positive effect on inefficiency in unit 103 than in unit 101 . Majority of the share cultivators in unit 103 were found to be in debt. Another important factor that affected technical efficiency was farmer participation in farmer organization activities. Reduction of inefficiency with participation in farmer organization activities was shown to be higher with negative significance level in unit 101than in unit 103. This was due to poor 
participation of farmers in the farmer organization activates in unit 103. Part time farming and age of farmers showed expected positive sign. However, these were not statistically significant. Distance from home did not account for technical efficiency.

\section{Farmer Organizations and Technical Efficiency}

To test the hypothesis on farmer organization relationship with technical efficiency, Chi square analysis was employed. A farmer participation score was calculated based on farmers' memberships in years, attendance of farmers in farmer organization meetings and attitudes of farmers on farmer organization activities. The Table 4 indicates this relationship.

Farmer participation in farmer organization was significant in the model. For unit 101, the use of dummy for share cultivator did not contribute to greater changes in the coefficients of the variables used in the model. With higher farmers participation score, the mean technical efficiency increased with less coefficient of variance. Table 4 shows that farmers had equal distribution of low, average and high level of participation scores. About $67 \%$ of the farmers had above the average participation score. The table further reveals that about one third of the farmers who had low participation score were operating with less than $80 \%$ technical efficiency. This confirms the previous results (see Table 3) that support the importance of farmer organization for the improvement of technical efficiency in Bethma cultivation.

Farmer organizations select the share cultivator for each owner under Bethma cultivation. The relationship between the owner and the share cultivators become important for the successful implementation of the Bethma system. Further, the study evidenced that the existing technical, legal and institutional framework in the Bethma is not free form malpractice. 
Table 4: $\quad$ Farmer participation score and the technical efficiency of Bethma cultivators, Yala 2004, units 101 and 103 Madatugama block

\begin{tabular}{|c|c|c|c|c|c|c|c|c|}
\hline \multirow{3}{*}{$\begin{array}{l}\text { Participation } \\
\text { Score }\end{array}$} & \multicolumn{8}{|c|}{ Technical Efficiency } \\
\hline & \multicolumn{4}{|c|}{ Unit 101} & \multicolumn{4}{|c|}{ Unit 103} \\
\hline & 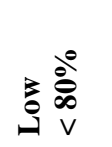 & 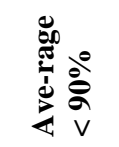 & 응 & 苞 & 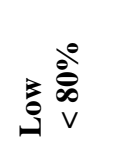 & 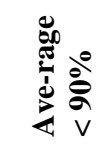 & 施 & $\frac{\pi}{0}$ \\
\hline Low $<5$ & 11 & 04 & 05 & $\begin{array}{l}20 \\
25 \%\end{array}$ & 24 & 07 & 01 & $\begin{array}{l}32 \\
40 \%\end{array}$ \\
\hline Average $5 \geq<10$ & 08 & 10 & 09 & $\begin{array}{l}27 \\
34 \%\end{array}$ & 17 & 10 & 06 & $\begin{array}{l}33 \\
41 \%\end{array}$ \\
\hline High $>10$ & 02 & 18 & 13 & $\begin{array}{l}33 \\
41 \%\end{array}$ & 01 & 11 & 03 & $\begin{array}{l}15 \\
19 \%\end{array}$ \\
\hline Total & $\begin{array}{l}21 \\
26 \%\end{array}$ & $\begin{array}{l}32 \\
40 \%\end{array}$ & $\begin{array}{l}27 \\
34 \%\end{array}$ & $\begin{array}{l}80 \\
100 \%\end{array}$ & $\begin{array}{l}42 \\
53 \%\end{array}$ & $\begin{array}{l}28 \\
35 \%\end{array}$ & $\begin{array}{l}10 \\
12 \%\end{array}$ & $\begin{array}{l}80 \\
100 \%\end{array}$ \\
\hline $\mathrm{X}^{2}$ Test & $\begin{array}{l}105.17 \\
\text { P: } 0.01\end{array}$ & (d.f: 4) & Cr. & Value 13.3 & $\begin{array}{l}53.17 \\
\text { P: } 0.01\end{array}$ & (d.f: 4) & Cr. V & alue 13.3 \\
\hline
\end{tabular}

\section{Conclusions}

This study has examined the issue of productivity efficiency between owner and the share cultivators utilizing the stochastic frontier function methodology. The results from the study indicate a substantial difference between productivity efficiency between these farmers. The sharecroppers have a substantially lower efficiency and productivity than owner cultivators. The overall technical efficiency of owners and share cultivators were $88 \%$ and $76 \%$ respectively. There was significant difference between technical efficiency within share cultivators, $77 \%$ and $65 \%$ in unit 1 and unit 3 respectively. There is scope for an increase in technical efficiency by $24 \%$ among share cultivators in unit 103.

Farmers' debt level affects technical efficiency among both owner and share cultivators. It was found that the cash from non-farm earnings could help stimulate farm investments and improve agricultural productivity. Ownership and participation in farmer organization activities are the major factors affecting technical efficiency among share cultivators. 
More participation of farmers in farmer organization activities could improve agricultural production efficiency under the Bethma cultivation system. Farmer organizations can play an important role in successful implementation of the Bethma cultivation programme. The potential of farmer organisations and their weaknesses need more investigation to improve and strengthen the farmer organisations.

\section{References}

Abeyratne, S. and J. Perera (1986). Change and Continuity in Village Irrigation Systems: A Case Study in the Moneragala District. Colombo. Agrarian Research and Training Institute Study, (75).

Aigner, D., C.A.K. Lovell and P. Schmidt (1977). Formulation and Estimation of Stochastic Frontier Production Function Models. Journal of Econometrics, 6(2):21-37.

Battese, G.E. and T.J. Coelli (1992). Frontier Production Functions, Technical Efficiency and Panel Data: With Application to Paddy Farmers in India. Journal of Productivity Analysis, 3(1):153-169.

Battese, G.E and T.J. Coelli (1993). A Stochastic Frontier Production Function Incorporating a Model for Technical Inefficiency Effects. Working Papers in Econometrics and Applied Statistics, No. 69, Department of Econometrics, University of New England, Armiodale.

Battese, G.E (1992). Frontier Production Functions and Technical Efficiency: A Survey of Empirical Applications in Agricultural Economics. Agricultural Economics, 7(2):185-208.

Coelli T.J (1995). Recent Developments in Frontier Estimation and Efficiency Measurement. Australian Journal of Agricultural Economics, 39(1):219-245.

Coelli T.J and G.E. Battese (1996). Identification of Factors, Which Influence the Technical Inefficiency of Indian farmers. American Journal of Agricultural Economics, 73:1098-1104. 
Ekanayake, S.A.B. and S.K.W. Jayasuriya (1987). Measurement of Firm Specific Technical Efficiency: A Comparison of Methods. Journal of Agricultural Economics, 38(1):115-122.

Farrel, M.J (1957). The Measurement of Production Efficiency. Journal of Royal Statistical Society, Series A, (120):253-281.

de Jong, I.H. (1989). Fair and Unfair: A Study into the Bethma System in Two Sri Lankan Village Irrigation Systems, Working Paper No. 15, IIMI. Sri Lanka.

Karunaratne, M.A.K.H.S.S and H.M.G. Herath (1989). Efficiency of Rice Production Under Major Irrigation Conditions: A Frontier Production Function Approach, Tropical Agricultural Research, 1:142-158.

Leach, E.R. (1961). Pul Eliya: A Village in Ceylon: A Study of Land Tenure and Kinship. London: Cambridge University Press.

Reddy, M. (2002). Implication of Tenancy Status on Productivity and Efficiency: Evidence from Fiji. The Sri Lankan Journal of Agricultural Economics, 4(1):19-37.

Meeusen, W. and J. van den Broeck (1977). Efficiency Estimation form Cobb-Douglas Production Function with Composed Error. International Economic Review, 18(1):435-444.

Perera, J. (1986). Research on Village Irrigation Systems in Sri Lanka: A Review. In Strategies for Improving Minor Irrigation Systems in Sri Lanka. D. Groenfeldt, J. Alwis, and J. Perera (eds.), Colombo: IIMI, pp 3-12.

Sathivadevel, R. and K.V. Raju (1996). Water Distribution and Irrigation System Performance: Rules \& Uses Demand in Tambraparani System. Unpublished Manuscript, IIMI, Colombo.

Timmer, C.P. (1970). On Measuring Technical Efficiency. Food Research Institute Studies, Agricultural Economics Trade and Development. 912: 99-271. 
Thiruchelvam, S. (2004), Weighted Composite Performance Index for Assessing the Performance of Distributory Canal Farmer Organizations under Participatory Irrigation Management in Mahaweli System H, Sri Lanka. Proceedings of the International Conference on Sustainable Water Resources Management in the Changing Environment of the Monsoon Region November 17 - 19 2004. BMICH, Colombo, Sri Lanka. 